\title{
Metastasis-Associated Lung Adenocarcinoma Transcript 1
}

National Cancer Institute

\section{Source}

National Cancer Institute. Metastasis-Associated Lung Adenocarcinoma Transcript 1. NCI Thesaurus. Code C92698.

Metastasis-associated lung adenocarcinoma transcript $1(\sim 8.7 \mathrm{~kb})$ is encoded by the human MALAT1 gene. This non-coding RNA may play a role in cancer and metastasis. 